\title{
Immunologically Reactive Equivalents of Fibrinogen in Sera and Urine of Children with Renal Disease
}

\author{
H. EKERT,* T. M. BARRATT, C. CHANTLER, and M. W. TURNER \\ From the Departments of Haematology and Immunology, Institute of Child Health, University of London
}

\begin{abstract}
Ekert, H., Barratt, T. M., Chantler, C., and Turner, M. W. (1972). Archives of Disease in Childhood, 47, 90. Immunologically reactive equivalents of fibrinogen in sera and urine of children with renal disease. Fibrin degradation products (FDP) were assayed by the tanned red cell haemagglutination inhibition technique in the sera and urine of children with renal disease, and their correlation with other parameters of proteinuria was examined. Urinary FDP were present in greater quantities in subjects with heavy and unselective proteinuria, and were not correlated with serum levels of FDP. FDP may derive from fibrinogen filtered through leaky glomeruli or from intravascular coagulation restricted to the kidney: the data presented are compatible with either hypothesis.
\end{abstract}

It is known that intravascular coagulation (IVC) and glomerular deposition of fibrin are involved in the pathogenesis of immunologically induced nephritis in the experimental animal (Vassalli and McCluskey, 1964, 1965), but in man the evidence is less secure. Intravascular coagulation has been demonstrated in patients with the haemolytic-uraemic syndrome (Sanchez Avalos et al., 1970; Gilchrist et al., 1969). Fibrin can be demonstrated by immunofluorescence in the glomeruli of some patients with various forms of glomerulonephritis (Koffler and Paronetto, 1965; McCluskey et al., 1966). Immunologically reactive equivalents of fibrinogen (fibrin degradation products; FDP) have been shown in the sera of patients with various types of nephritis (Wardle and Taylor, 1968; Stiehm and Trygstad, 1969), though some of the methods used have been criticized (Ekert, 1970a, b). Heparin modifies experimental glomerulonephritis (Halpern et al., 1965) and uncontrolled studies suggest that it has a beneficial effect in the haemolytic-uraemic syndrome (Gilchrist et al., 1969), in anuric acute glomerulonephritis (KincaidSmith, Saker, and Fairley, 1968), and in some cases of persistent glomerulonephritis (Herdman et al., 1970; Kincaid-Smith, Laver, and Fairley, 1970).

It seems possible that IVC confined to the kidney

Received 29 June 1971.

^Present address: Department of Haematology, Royal Children's Hospital, Flemington Road, Parkville, Victoria 3052, Australia. might contribute to the pathogenesis of some forms of glomerulonephritis and that the presence of FDP in the urine might be a more sensitive index of glomerular fibrin deposition than serum FDP (Rayner et al., 1969). FDP have been demonstrated in the urine of patients undergoing renal transplant rejection (Braun and Merrill, 1968; Antoine, Neveu, and Ward, 1969; Clarkson, Morton, and Cash, 1970b) and of patients with disseminated IVC (Coopland et al., 1968;Herschlein and Steichele, 1968), glomerulonephritis (Rayner et al., 1969; Naish et al., 1970; Vermylen et al., 1970), and acute ischaemic renal failure (Clarkson et al., 1970a). However, explanations other than localized IVC could be invoked to account for FDP in the urine: the filtered load of FDP might be increased because of raised serum levels or increased glomerular permeability, or impairment of tubular protein reabsorption. Alternatively, urinary FDP might derive from fibrinogen filtered through a damaged glomerulus (Yatzidis, 1964) and degraded by fibrinolytic mechanisms normally present in urine. We have attempted to analyse this problem by assaying urinary FDP in children with a wide range of renal diseases, and relating it to other parameters of protein excretion.

\section{Methods}

Venous blood was drawn in plastic disposable syringes. The sample for estimation of albumin, creatinine, lysozyme, IgG, and C3 was anticoagulated with lithium sequestrene. For fibrinogen estimation, 
blood was anticoagulated with $\mathbf{3 \cdot 8} \%$ trisodium citrate (1 vol anticoagulant: 9 vol blood) and platelet-poor plasma was prepared by centrifugation at $3500 \mathrm{~g}$ for 20 minutes. Blood for FDP estimation was collected into plain glass tubes containing EACA $1 \mathrm{mg} / \mathrm{ml}$, and allowed to clot at $37^{\circ} \mathrm{C}$ for 1 to 3 hours; the serum was separated by centrifugation, thrombin (10 NIH units) added, and incubated again at $37^{\circ} \mathrm{C}$ for a further 30 minutes. Plasma and serum samples were stored at $-20^{\circ} \mathrm{C}$ until assay.

24-hour urine samples were collected into plastic containers to which thiomersalyl $(20 \mathrm{mg})$ and aprotinin (500 units) had been added. An aliquot of $100 \mathrm{ml}$ was removed and dialysed using $23 / 32 \mathrm{~mm}$ Visking tubing (Union Carbide Company, Chicago, Ill., U.S.A.) against cold running tap water $(24 \mathrm{hr})$ and finally six changes of distilled water. The dialysed samples were then lyophilized and reconstituted before analysis in $2 \mathrm{ml}$ phosphate-citrate buffer (Merskey, Lalezari, and Johnson, 1969). Albumin recovery from this fiftyfold concentration procedure was $70 \%$.

FDP in serum ( $S_{F D P}$, unconcentrated urine ( $U_{F D P}$, and concentrated urine (U'FDP) were assayed by the tanned red cell haemagglutination inhibition technique (TRCHI) (Merskey et al., 1969). Doubling dilutions on lucite plates were performed using a Cornwall automatic syringe. Human group $O$ red cells coated with fibrinogen and a 1/8000 dilution of antifibrinogen antiserum (Wellcome Laboratories, Beckenham, Kent) were used. The antiserum was shown to be monospecific by immunoelectrophoresis against human plasma. Results are expressed as the logarithm (base 2) of the reciprocal of doubling dilution titres. The observed range for $S_{\text {FDP }}$ in hospitalized children with unrelated disease was $<1-4$. Pooled normal human urine was shown not to interfere with the TRCHI assay.

Recovery experiments on the effect of concentration of urine samples on the FDP showed that the titre observed in the concentrated urine almost invariably exceeded that in the unconcentrated urine by a factor greater than that which could be attributed to the degree of concentration alone (see Table II). Dilution of the concentrated urine to its original volume resulted in FDP titres similar to those observed in the unconcentrated urine, and so the effect cannot be attributed to removal of an inhibitor of the TRCHI assay by dialysis or the generation of more immunoreactive material during the concentrating procedure. High concentrations of albumin in the urine concentrates may have contributed to this effect (C. Merskey, A. J. Johnson, and P. Lazelari, 1971, personal communication) and systematic inaccuracies of doubling dilution techniques have been described (Merskey et al., 1971, personal communication). We have no satisfactory explanation of this phenomenon, but since there is a significant rank order correlation between the data on concentrated and unconcentrated urine specimens (Spearman; $P<0.01$ ) we have used the data from concentrated specimens and analysed them by non-parametric statistical techniques.

The methods of estimating the clearances of albumin (Barratt, McLaine, and Soothill, 1970) $\left(\mathrm{C}_{\mathrm{alb}}\right)$, creati- nine (Barratt et al., 1970) ( $\left.\mathrm{C}_{\text {creat }}\right)$, and lysozyme (Barratt and Crawford, 1970) ( $C_{\text {lys }}$ ), and of the plasma C3 (Ngu and Soothill, 1969) and fibrinogen (Jacobsson, 1955) concentrations are described elsewhere. Urinary fibrinogen was measured by the method of Yatzidis (1964). IgG was measured by the single radial gel diffusion method (Mancini, Carbonara, and Heremans, 1965), and selectivity of proteinuria $\left(\mathrm{C}_{\mathrm{IgG}} / \mathrm{C}_{\mathrm{alb}}\right)$ was calculated when proteinuria was moderate or heavy $\left(\mathrm{C}_{\text {alb }} / \mathrm{C}_{\text {creat }}>0.2 \times 10^{-3}\right)$.

\section{Patients}

Thirty-one children with renal disease and 6 healthy adults were studied. Details of clinical features and renal function are given in Table $I$.

(i) Nephrotic syndrome. Twelve children had heavy proteinuria $\left(\mathrm{C}_{\mathrm{alb}} / \mathrm{C}_{\text {creat }}>1.0 \times 10^{-3}\right)$. Six responded to steroid therapy: of these, 5 had highly selective proteinuria $\left(\mathrm{C}_{\mathrm{IgG}} / \mathrm{C}_{\mathrm{alb}}<20 \%\right.$ ) and those investigated had no abnormality of renal histology on light microscopy. One (Case 5) is included in this group, even though at the time of study his glomerular leak did not reach nephrotic proportions, because of the similarity of renal histology and protein selectivity. The other 6 children were steroid resistant (prednisolone $2 \mathrm{mg} / \mathrm{kg}$ per day for 4 weeks) or presumed to be so (Case 12; congenital nephrotic syndrome); 4 had poorly selective proteinuria $\left(\mathrm{C}_{\mathrm{IgG}} / \mathrm{C}_{\mathrm{alb}}>20 \%\right)$; and 3 had proliferative changes on renal biopsy.

(ii) Acute nephritic syndrome. Three children had acute nephritis: haematuria, proteinuria, oedema, and hypertension of less than 3 weeks' duration. In 2, the illness followed a streptococcal throat infection, but in one (Case 13) no evidence of a streptococcal aetiology was discovered. All had low C3 levels.

(iii) Persistent glomerulonephritis. Twelve children had moderate proteinuria $\left(\mathrm{C} /\right.$ alb $\mathrm{C}_{\text {creat }}>0.01$ $\times 10^{-3}$ ) for more than 6 months and proliferative changes on renal biopsy. In three the disease followed an episode of acute nephritis, though a streptococcal aetiology was not demonstrated in any. Four cases were associated with Henoch-Schönlein purpura; one of these cases (Case 24) has been included in this group even though renal biopsy had not been performed.

(iv) Recurrent haematuria. Two children had recurrent haematuria with little or no increase in albumin excretion, normal cystoscopy, and normal renal biopsy.

(v) Fanconi syndrome. One child had cystinosis with multiple tubular dysfunction and a tubular pattern of proteinuria $\left(\mathrm{C}_{\text {lys }} / \mathrm{C}_{\text {creat }}>150 \times 10^{-3}\right)$.

(vi) Haemolytic-uraemic syndrome. One child was studied with the characteristic syndrome of haemolysis and fragmented erythrocytes, thrombocytopenia, and oliguria. 
TABLE I

Clinical Details of Patients Studied

\begin{tabular}{|c|c|c|c|c|c|c|c|c|c|c|}
\hline $\begin{array}{l}\text { Case } \\
\text { No. }\end{array}$ & $\begin{array}{l}\text { Age } \\
(\mathbf{y r})\end{array}$ & Histology $y^{\star}$ & $\begin{array}{c}\text { Steroid } \\
\text { Response }\end{array}$ & Haematuria $†$ & $\begin{array}{c}\text { Plasma } \\
\text { C3 } \\
\% \text { RNS }\end{array}$ & $\begin{array}{c}\mathrm{C}_{\text {creat }} \\
\mathrm{ml} / \mathrm{min} \text { per } \\
1 \cdot 73 \mathrm{~m}^{2} \mathrm{SA}\end{array}$ & $\begin{array}{c}\mathrm{C}_{\text {alb }} / \mathrm{C}_{\text {creat }} \\
\times 10^{3}\end{array}$ & $\begin{array}{c}\mathrm{C}_{\mathrm{IgG}} / \mathrm{C}_{\mathrm{alb}} \\
\times 10^{2}\end{array}$ & $\begin{array}{c}\mathrm{Clys}_{\text {lys }} / \mathrm{C}_{\text {creat }} \\
\times 10^{3}\end{array}$ & Comment§ \\
\hline $\begin{array}{l}\text { Healthy } \\
\text { Range of } \\
\text { observati }\end{array}$ & $\begin{array}{l}n=6) \\
\text { ons: } \\
25-44\end{array}$ & - & - & 0 & $54-230 \ddagger$ & $117-171$ & $\begin{array}{r}0.00087- \\
0.0036\end{array}$ & - & $0 \cdot 58-2 \cdot 1$ & \\
\hline $\begin{array}{c}\text { Nephroti } \\
1 \\
2 \\
3 \\
4 \\
5 \\
6 \\
7 \\
8 \\
9 \\
10 \\
11 \\
12\end{array}$ & \begin{tabular}{r|} 
syndron \\
4 \\
13 \\
3 \\
4 \\
7 \\
2 \\
10 \\
4 \\
10 \\
6 \\
6 \\
$0 \cdot 1$
\end{tabular} & $\begin{array}{l}m e \\
M C \\
M C \\
- \\
M \bar{C} \\
- \\
\text { FGS } \\
M C \\
\text { CGN } \\
P \\
P \\
P\end{array}$ & $\begin{array}{l}S \\
S \\
S \\
S \\
S \\
S \\
R \\
R \\
R \\
R \\
R \\
-\end{array}$ & $\begin{array}{c}0 \\
0 \\
0 \\
0 \\
0 \\
+ \\
0 \\
0 \\
+ \\
0 \\
0 \\
0\end{array}$ & $\begin{array}{r}92 \\
112 \\
196 \\
116 \\
96 \\
148 \\
68 \\
88 \\
160 \\
112 \\
112 \\
80\end{array}$ & $\begin{array}{c}47 \\
74 \\
111 \\
101 \\
126 \\
64 \\
136 \\
51 \\
6 \cdot 0 \\
151 \\
148 \\
36\end{array}$ & $\begin{array}{l}11 \\
1 \cdot 7 \\
38 \\
1 \cdot 0 \\
0 \cdot 69 \\
3 \cdot 3 \\
4 \cdot 7 \\
13 \\
32 \\
1 \cdot 9 \\
1 \cdot 3 \\
9 \cdot 6\end{array}$ & $\begin{array}{c}3 \cdot 1 \\
19 \\
7 \cdot 8 \\
3 \cdot 7 \\
5 \cdot 9 \\
23 \\
12 \\
28 \\
65 \\
34 \\
24 \\
3 \cdot 9\end{array}$ & $\begin{array}{c}0 \cdot 78 \\
0.71 \\
0 \cdot 61 \\
0 \cdot 84 \\
0.49 \\
0 \cdot 83 \\
0 \cdot 34 \\
6 \cdot 8 \\
100 \\
0.65 \\
1.0 \\
2 \cdot 0\end{array}$ & Congenital \\
\hline $\begin{array}{c}\text { Acute ne } \\
13 \\
14 \\
15\end{array}$ & $\begin{array}{c}\text { hritic sy } \\
13 \\
5 \\
12\end{array}$ & $\begin{array}{r}\text { yndrome } \\
\mathrm{P}+\mathrm{C} \\
-\end{array}$ & $\bar{z}$ & $\begin{array}{l}++ \\
++ \\
-\end{array}$ & $\begin{array}{l}56 \\
54 \\
50\end{array}$ & $\begin{array}{l}9 \cdot 1 \\
33 \\
77\end{array}$ & $\begin{array}{l}28 \\
0 \cdot 67 \\
1 \cdot 8\end{array}$ & $\begin{array}{l}42 \\
43 \\
9 \cdot 9\end{array}$ & $\begin{array}{c}<8 \cdot 8 \\
12 \\
0.83\end{array}$ & $\begin{array}{l}\text { Strep 0 } \\
\text { Strep + } \\
\text { Strep + }\end{array}$ \\
\hline $\begin{array}{c}\text { Persisten } \\
16 \\
17 \\
18 \\
19 \\
20 \\
21 \\
22 \\
23 \\
24 \\
25 \\
26 \\
27\end{array}$ & \begin{tabular}{r|} 
glomer \\
8 \\
11 \\
7 \\
5 \\
10 \\
14 \\
8 \\
10 \\
7 \\
9 \\
6 \\
14
\end{tabular} & $\begin{array}{l}\text { ulonephritis } \\
\mathrm{P}+\mathrm{C} \\
\mathrm{CGN} \\
\mathrm{P} \\
\mathrm{P} \\
\mathrm{P} \\
\mathrm{P} \\
\mathrm{P} \\
\mathrm{P} \\
\mathrm{P} \\
\mathrm{P} \\
\mathrm{CGN} \\
\mathrm{P}\end{array}$ & $\begin{array}{l}z \\
= \\
z \\
z \\
z \\
z \\
=\end{array}$ & $\begin{array}{c}+ \\
+ \\
0 \\
0 \\
+ \\
+ \\
++ \\
+ \\
+ \\
0 \\
++ \\
0\end{array}$ & $\begin{array}{r}144 \\
60 \\
92 \\
164 \\
136 \\
172 \\
124 \\
104 \\
100 \\
94 \\
112 \\
100\end{array}$ & $\begin{array}{r}143 \\
95 \\
159 \\
178 \\
144 \\
91 \\
136 \\
170 \\
107 \\
106 \\
143 \\
147\end{array}$ & $\begin{array}{l}0 \cdot 20 \\
0 \cdot 84 \\
0 \cdot 086 \\
0 \cdot 84 \\
0 \cdot 012 \\
0 \cdot 19 \\
0 \cdot 093 \\
0 \cdot 72 \\
0 \cdot 24 \\
0 \cdot 028 \\
0 \cdot 15 \\
0.90\end{array}$ & $\begin{array}{l}\frac{14}{20} \\
\frac{11}{16} \\
\frac{8}{8 \cdot 4} \\
\frac{17}{24} \\
34\end{array}$ & $\begin{array}{l}1 \cdot 4 \\
0 \cdot 83 \\
0 \cdot 34 \\
- \\
0 \cdot 73 \\
0 \cdot 40 \\
0 \cdot 72 \\
0 \cdot 51 \\
1 \cdot 2 \\
0 \cdot 52 \\
0 \cdot 71 \\
1 \cdot 0\end{array}$ & $\begin{array}{l}\text { ANS } \\
\text { ANS } \\
\text { ANS } \\
\\
\text { HSP } \\
\text { HSP } \\
\text { HSP } \\
\text { HSP }\end{array}$ \\
\hline $\begin{array}{l}\text { Recurren } \\
28 \\
29\end{array}$ & $\begin{array}{c}\text { haemat } \\
15 \\
6\end{array}$ & $\begin{array}{l}\text { uria } \\
\text { MC } \\
\text { MC }\end{array}$ & $\overline{-}$ & $\begin{array}{c}++ \\
+\end{array}$ & $\begin{array}{r}80 \\
108\end{array}$ & $\begin{array}{l}171 \\
170\end{array}$ & $\begin{array}{l}0.018 \\
0 \cdot 0057\end{array}$ & - & $\begin{array}{r}1.4 \\
<0.1\end{array}$ & \\
\hline $\begin{array}{l}\text { Fanconi } \\
\quad 30\end{array}$ & $\begin{array}{c}\text { yndrome } \\
2\end{array}$ & - & - & 0 & 88 & - & $0 \cdot 21$ & - & $>150$ & Cystinosis \\
\hline $\begin{array}{c}\text { Haemoly } \\
31\end{array}$ & $\begin{array}{c}\text {-uraem } \\
4\end{array}$ & $\begin{array}{l}\text { nic syndrome } \\
\text { HUS }\end{array}$ & - & ++ & 116 & $4 \cdot 6$ & 14 & 61 & 75 & \\
\hline
\end{tabular}

${ }^{\star} \mathrm{MC}$, minimal change; FGS, focal glomerular sclerosis; CGN, chronic glomerulonephritis; $P$, proliferative glomerulonephritis; $\mathrm{C}$, crescents; HUS, changes characteristic of haemolytic-uraemic syndrome.

+++ , macroscopic; + , microscopic.

¡Plasma C3 expressed as percentage of reference serum. The range given for healthy subjects is that reported for children by Ngu and Soothill (1969).

§Strep, evidence of streptococcal infection (culture or ASO $>800 \mathrm{U} / \mathrm{ml}$ ); ANS, acute nephritic syndrome at onset; HSP, Henoch-Schönlein purpura.

\section{Results}

The results of plasma fibrinogen levels and serum and urinary FDP levels are shown in Table II.

Fibrinogen. The plasma fibrinogen levels were either normal or raised in the children with renal disease. No clottable fibrinogen was detected in either fresh or concentrated urine.
Serum FDP. The child with the haemolyticuraemic syndrome (Case 31) had the highest $S_{\text {FDP }}$ titre. Two children with acute nephritis (Cases 13 and 14) and one with persistent glomerulonephritis (Case 17; acute nephritic onset) had $S_{\text {FDP }}$ titres greater than the healthy adults; the remaining 27 children did not have raised $S_{F D P}$ levels (Table II). 
TABLE II

Plasma Fibrinogen and Fibrin Degradation Products in Sera and Urine

\begin{tabular}{|c|c|c|c|c|}
\hline Case No. & $\begin{array}{l}\text { Plasma Fibrinogen } \\
(\mathrm{mg} / 100 \mathrm{ml})\end{array}$ & SFDP & $\begin{array}{c}\text { UFDP } \\
\text { (fresh) }\end{array}$ & $\begin{array}{c}\mathbf{U}^{\prime} \mathbf{F D P} \\
\text { (concentrated) }\end{array}$ \\
\hline $\begin{array}{l}\text { Healthy }(\mathrm{n}=6) \\
\text { Range of observations }\end{array}$ & $155-187$ & $1-4$ & $<1$ & $<1$ \\
\hline $\begin{array}{r}\text { Nephrotic syndrome } \\
1 \\
2 \\
3 \\
4 \\
5 \\
6 \\
7 \\
8 \\
9 \\
10 \\
11 \\
12\end{array}$ & $\begin{array}{r}186 \\
536 \\
459 \\
340 \\
588 \\
763 \\
526 \\
839 \\
526 \\
479 \\
454\end{array}$ & $\begin{array}{l}2 \\
4 \\
3 \\
3 \\
3 \\
3 \\
4 \\
4 \\
2 \\
4 \\
3 \\
4 \\
4\end{array}$ & $\begin{aligned}<1 \\
1 \\
<1 \\
<1 \\
<1 \\
<1 \\
<1 \\
<1 \\
\quad 12 \\
\quad 2 \\
2 \\
<1\end{aligned}$ & $\begin{array}{r}3 \\
12 \\
4 \\
1 \\
4 \\
9 \\
4 \\
4 \\
16 \\
20 \\
17 \\
13 \\
6\end{array}$ \\
\hline $\begin{array}{c}\text { Acute nephritic syndrome } \\
13 \\
14 \\
15\end{array}$ & $\frac{541}{278}$ & $\begin{array}{l}5 \\
5 \\
4\end{array}$ & $\begin{array}{r}1 \\
1 \\
<1\end{array}$ & $\begin{array}{r}11 \\
8 \\
3\end{array}$ \\
\hline $\begin{array}{c}\text { Persistent glomerulonephritis } \\
16 \\
17 \\
18 \\
19 \\
20 \\
21 \\
22 \\
23 \\
24 \\
25 \\
26 \\
27\end{array}$ & $\begin{array}{l}485 \\
273 \\
233 \\
665 \\
273 \\
349 \\
330 \\
263 \\
350 \\
321 \\
342 \\
289\end{array}$ & $\begin{array}{l}3 \\
5 \\
4 \\
4 \\
4 \\
2 \\
3 \\
4 \\
2 \\
3 \\
3 \\
3 \\
2\end{array}$ & $\begin{array}{r}<1 \\
<1 \\
<1 \\
<1 \\
<1 \\
<1 \\
<1 \\
1 \\
1 \\
1 \\
<1 \\
2 \\
2 \\
2\end{array}$ & $\begin{array}{r}4 \\
8 \\
6 \\
3 \\
6 \\
4 \\
6 \\
7 \\
6 \\
5 \\
13 \\
16\end{array}$ \\
\hline $\begin{array}{r}\text { Recurrent haematuria } \\
28 \\
29\end{array}$ & $\begin{array}{l}205 \\
324\end{array}$ & $\begin{array}{l}2 \\
4\end{array}$ & $\begin{array}{l}<1 \\
<1\end{array}$ & $\begin{array}{l}5 \\
6\end{array}$ \\
\hline $\begin{array}{r}\text { Fanconi syndrome } \\
30\end{array}$ & 209 & 3 & $<1$ & 2 \\
\hline $\begin{array}{l}\text { Haemolytic-uraemic syndrome } \\
31\end{array}$ & 356 & 6 & 9 & 25 \\
\hline
\end{tabular}

Note: FDP are expressed as the logarithm (base 2) of reciprocal titres.

Urine FDP. FDP were detected in the concentrates of urine samples of all the children studied but in none of the urine concentrates of the 6 healthy adults (Table II). The range of titres observed in the concentrated urines (U'FDP) was so wide that corrections for urine flow rate or creatinine clearance would have little effect upon the interpretation of the data and have therefore been omitted.

No correlation between FDP in serum and concentrated urine was observed ( $P>0.1$; Spearman). However, the child with the haemolytic uraemic syndrome (Case 31) had the highest FDP titre in both serum and urine.

In the 24 children with moderate or heavy proteinuria $\left(\mathrm{C}_{\text {alb }} / \mathrm{C}_{\text {creat }}>0 \cdot 2+10^{-3}\right)$ there was a significant correlation between the selectivity of proteinuria, $\mathrm{C}_{\mathrm{IgG}} / \mathrm{C}_{\mathrm{alb}}$, and the FDP titres in urine concentrates, $U^{\prime}{ }_{F D P}(P<0.01$; Spearman): those with the least selective proteinuria had the highest titre of FDP (Fig. 1). In the 11 children with poorly selective proteinuria $\left(\mathrm{C}_{\mathrm{IgG}} / \mathrm{C}_{\mathrm{alb}}>\right.$ $20 \%$ ), U'FDP was significantly correlated with $\mathrm{C}_{\text {alb }} / \mathrm{C}_{\text {creat }}(\mathrm{P}<0.05$; Spearman $)$ : thus increased glomerular permeability for albumin is accompanied by increased excretion of FDP. No correlation between $\mathrm{C}_{\text {alb }} / \mathrm{C}_{\text {creat }}$ and $\mathrm{U}^{\prime}{ }_{\mathrm{FDP}}$ was observed in patients with more selective proteinuria (Fig. 2). The 2 children (Cases 31 and 9) with poorly selective proteinuria and very high levels of U'FDP also had 


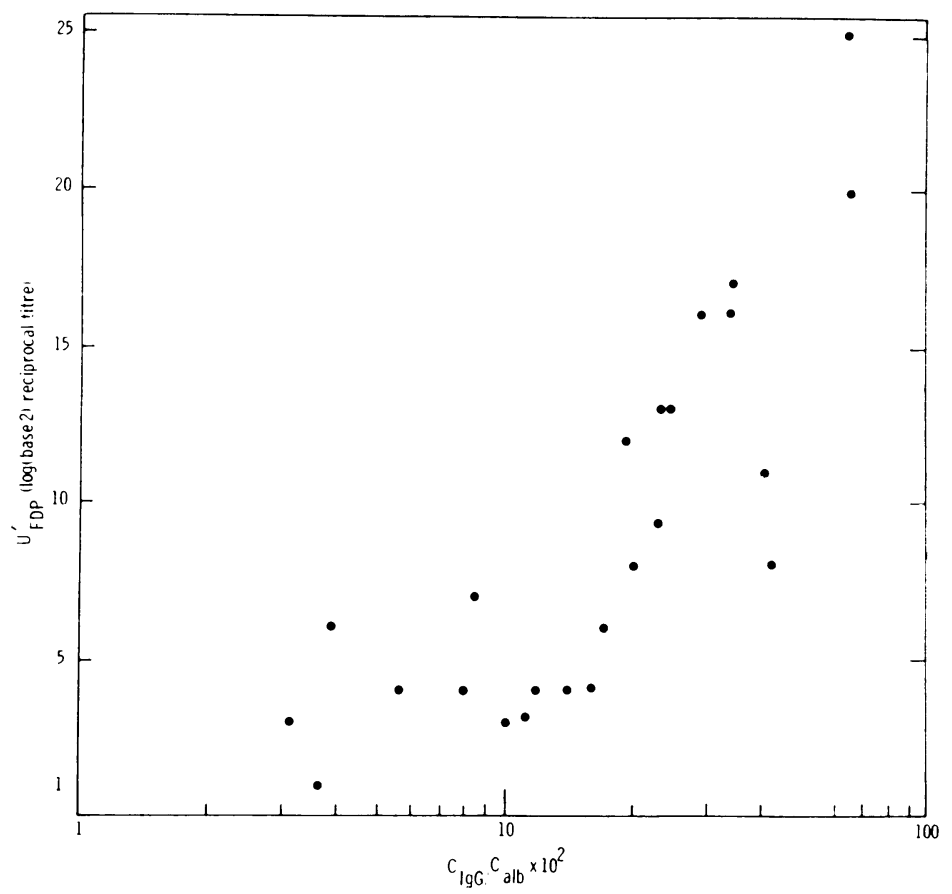

FIG. 1.-The relation between urinary FDP in concentrated urine $\left(U_{F D P}^{\prime}\right)$ and the selectivity of proteinuria $\left(C_{I g} G / C_{a l b}\right)$ in children with moderate or heavy proteinuria $\left(C_{a l b} / C_{c r e a t} \geqslant 0 \cdot 2 \times 10^{-3}\right)$.

a considerable increase of lysozyme excretion. However, they had low levels of creatinine clearance and therefore raised plasma lysozyme: under such circumstances increased lysozyme excretion does not necessarily imply impaired tubular reabsorption of protein (Harrison et al., 1968). Tubular proteinuria itself is not necessarily associated with a high value for $U^{\prime}$ FDP as in the patient with the Fanconi syndrome (Case 30).

Median U'FDP levels did not differ in patients with and without haematuria ( $P>0 \cdot 1$; Wilcoxon). Some subjects, e.g. Case 22, who had heavy haematuria, had low levels of FDP in the urine.

\section{Discussion}

Raised FDP levels in the sera of patients with glomerulonephritis have been previously reported (Wardle and Taylor, 1968; Stiehm and Trygstad, 1969): the highest titres we observed were in 2 children with acute glomerulonephritis (Cases 13 and 14), in 1 child with persistent glomerulonephritis following an acute nephritic onset (Case 17), and in the child with the haemolytic-uraemic syndrome (Case 31 ).

The presence of material antigenically related to fibrinogen has been shown previously in the urine of patients with renal disease (Rayner et al., 1969; Clarkson et al., 1970a,b). However, it has not been certain whether the excretion of fibrinogen and FDP exceeds that which might be expected on the grounds of proteinuria alone. Analysis of FDP excretion by classical differential protein clearance theory (Hardwicke et al., 1970) is restricted by ignorance of its physicochemical characteristics, by the quantitative uncertainty of the TRCHI technique (Ekert, 1970a,b), and by the number of theoretically possible origins of urinary FDP.

Thus FDP may be produced intravascularly and excreted through normal glomeruli or damaged glomeruli with varying permeability for proteins of different molecular size and might be subject to tubular reabsorption. Alternatively, FDP may be released following deposition of fibrinogen in glomeruli and passage into Bowman's capsule, or intact fibrinogen might be filtered through the glomeruli and degraded by fibrinolytic systems present in normal urine. The correlation of urinary FDP with selectivity of proteinuria, and, within the poorly selective group, with albumin excretion, is directly compatible with the latter 


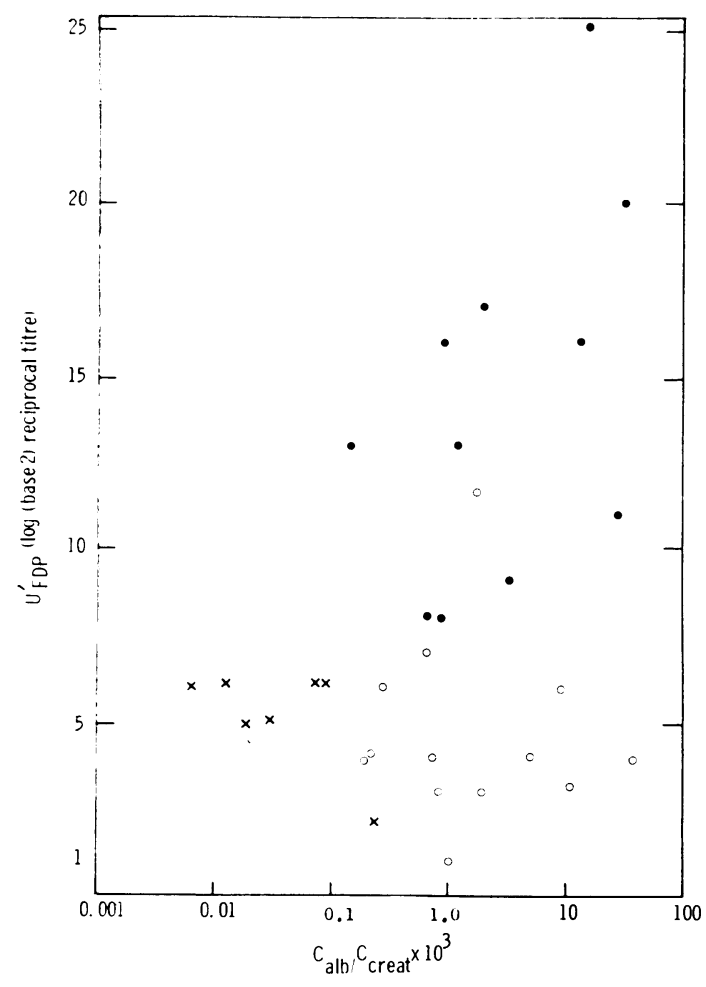

FIG. 2.-The relation between urinary FDP in concentrated urine $\left(U_{F D P}^{\prime}\right)$ and albumin excretion $\left(C_{a l b} / C_{c r e a t}\right.$ $=C_{I g G} / C_{a l b} \geqslant 20 \% ; \mathrm{O}=C_{I g G /} C_{a l b}<20 \% ; X=$ $C_{I g G} / C_{a l b}$ not measured.

hypotheses, but does not exclude the former, since localized IVC may be more active in subjects with heavy or unselective proteinuria.

The lack of correlation of FDP in urine and serum in our group of patients, and the low excretion of FDP in the patient (Case 30) with the Fanconi syndrome and tubular proteinuria suggest that urinary FDP do not usually arise from circulating FDP of low molecular weight; if this were so, FDP excretion would be increased with high serum levels or impaired low molecular weight protein reabsorption.

Two patients had exceptionally high U'FDP: one (Case 31) had the haemolytic-uraemic syndrome with raised $S_{F D P}$, but the other (Case 9), who had the most rapidly progressive glomerulonephritis in the group, had $S_{\text {FDP }}$ at the upper limit of normal. These 2 children also had high levels of FDP in unconcentrated urine (Case $31=9$, Case $9=12$ ). The highest level of FDP in random urines in the other patients was 5 .
It is possible that the urinary excretion of FDP may be a more sensitive reflection of glomerular fibrin deposition than raised titres of FDP in the serum, and provide a more rational basis for the selection of subjects who might benefit from anticoagulant therapy (Kincaid-Smith et al., 1968; Herdman et al., 1970; Kincaid-Smith et al., 1970), but other interpretations of the data have not been excluded; further clarification necessitates improvement of the present techniques of measurement and knowledge of the physicochemical characteristics of the degradation products of fibrin in the urine of patients with renal disease.

We thank Miss Danielle Montgomery, Mrs. Ayo Banwo, and Mr. A. Medlan for technical assistance, and Professor R. Hardisty and Professor J. F. Soothill for advice and encouragement.

REFERENCES

Antoine, B., Neveu, T., and Ward, P. D. (1969). Fibrinuria during renal transplantation. Transplantation, 8, 98.

Barratt, T. M., and Crawford, R. (1970). Lysozyme excretion as a measure of renal tubular dysfunction in children. Clinical Science, 39, 457.

Barratt, T. M., McLaine, P. N., and Soothill, J. F. (1970). Albumin excretion as a measure of glomerular dysfunction in children. Archives of Disease in Childhood, 45, 496.

Braun, W. E., and Merrill, J. P. (1968). Urine fibrinogen fragments in human renal allografts: a possible mechanism of renal injury. New England fournal of Medicine, 278, 1366.

Clarkson, A. R., MacDonald, M. K., Fuster, V., Cash, J. D., and Robson, J. S. (1970a). Glomerular coagulation in acute ischaemic renal failure. Quarterly fournal of Medicine, 39, 585.

Clarkson, A. R., Morton, J. B., and Cash, J. D. (1970b). Urinary fibrin/fibrinogen degradation products after renal homotransplantation. Lancet, 2, 1220.

Coopland, A. T., Israels, E. D., Zipursky, A., and Israels, L. G. (1968). The pathogenesis of defective hemostasis in abruptio placentae. American fournal of Obstetrics and Gynecology, $100,311$.

Ekert, H. (1970a). Fibrin split products in serum of newborn: possible technical errors. Pediatrics, 45, 154.

Ekert, H. (1970b). Fibrin/fibrinogen degradation products. (Letter to the Editor.) Archives of Disease in Childhood, 45, 438.

Gilchrist, G. S., Lieberman, E., Ekert, H., Fine, R. N., and Grushkin, C. (1969). Heparin therapy in the haemolytic-uraemic syndrome. Lancet, 1, 1123.

Halpern, B., Milliez, P., Lagrue, G., Fray, A., and Morard, J. C. (1965). Protective action of heparin in experimental immune nephritis. Nature (London), 205, 257.

Hardwicke, J., Cameron, J. S., Harrison, J. F., Hulme, B., and Soothill, J. F. (1970). Proteinuria, studied by clearances of individual macromolecules. In Proteins in Normal and Pathological Urine, p. 111 . Ed. by Y. Manuel, J. P. Revillard, and H. Betuel. Karger, Basle and New York.

Harrison, J. F., Lunt, G. S., Scott, P., and Blainey, J. D. (1968). Urinary lysozyme, ribonuclease, and low-molecular-weight protein in renal disease. Lancet, 1, 371.

Herdman, R. C., Edson, J. R., Pickering, R. J., Fish, A. J., Marker, S., and Good, R. A. (1970) Anticoagulants in renal disease in children. American fournal of Diseases of Children, 119, 27.

Herschlein, H. J., and Steichele, D. F. (1968). Immunochemischer Nachweis von Fibrinogenderivaten im Urin bei Verbrauchskoagulopathien. Thrombosis et diathesis haemorrhagica, 19, 248.

Jacobsson, K. (1955). Studies on the determination of fibrinogen in human blood plasma. Scandinavian fournal of Clinical and Laboratory Investigation, 7, Suppl. 14, 7. 
Kincaid-Smith, P., Laver, M. C., and Fairley, K. F. (1970). Dipyridamole and anticoagulants in renal disease due to glomerular and vascular lesions: a new approach to therapy. Medical Fournal of Australia, 1, 145.

Kincaid-Smith, P., Saker, B. M., and Fairley, K. F. (1968). Anticoagulants in 'irreversible' acute renal failure. Lancet, 2, 1360.

Koffler, D., and Paronetto, F. (1965). Immunofluorescent localization of immunoglobulins, complement, and fibrinogen in human diseases. II. Acute, subacute, and chronic glomerulonephritis. Fournal of Clinical Investigation, 44, 1665.

McCluskey, R. T., Vassalli, P., Gallo, G., and Baldwin, D. S. (1966). An immunofluorescent study of pathogenic mechanisms in glomerular diseases. New England fournal of Medicine, 274, 695.

Mancini, G., Carbonara, A. O., and Heremans, J. F. (1965). Immunochemical quantitation of antigens by single radial immunodiffusion. Immunochemistry, 2, 235.

Merskey, C., Lalezari, P., and Johnson, A. J. (1969). A rapid, simple sensitive method for measuring fibrinolytic split products in human serum. Proceedings of the Society for Experimental Biology and Medicine, 131, 871.

Naish, P. F., Sevitt, L. H., Pitney, W. R., and Peters, D. K. (1970). Fibrinogen derivatives in renal disease. (Abst.) Clinical Science, 39, 15P.

Ngu, J. L., and Soothill, J. F. (1969). Immunoconglutinin and complement changes in children with acute nephritis. Clinical and Experimental Immunology, 5, 557.

Rayner, H., Paraskevas, F., Israels, L. G., and Israels, E. D. (1969) Fibrinogen breakdown products: identification and assay in serum and urine. Fournal of Laboratory and Clinical Medicine, 74, 586.
Sanchez Avalos, J., Vitacco, M., Molinas, F., Peĩalver, J., and Gianantonio, C. (1970). Coagulation studies in the hemolyticuremic syndrome. Fournal of Pediatrics, 76, 538.

Stiehm, E. R., and Trygstad, C. W. (1969). Split products of fibrin in human renal disease. American fournal of Medicine, 46, 774.

Vassalli, P., and McCluskey, R. T. (1964). The pathogenic role of the coagulation process in rabbit Masugi nephritis. American Fournal of Pathology, 45, 653.

Vassalli, P., and McCluskey, R. T. (1965). The coagulation process and glomerular disease. American fournal of Medicine, 39, 179.

Vermylen, J., Dotremont, G., Gaetano, G., Donati, M. B., and Michielsen, P. (1970). Indomethacin and urinary excretion of fibrinogen-like material in proliferative glomerulonephritis. Revue Européenne d'Études Cliniques et Biologiques, $15,979$.

Wardle, E. N., and Taylor, G. (1968). Fibrin breakdown products and fibrinolysis in renal disease. Fournal of Clinical Pathology, 21, 140.

Yatzidis, H. (1964). Evidence of fibrinogenuria in the nephrotic syndrome. Nature (London), 201, 187.

Correspondence to Dr. T. M. Barratt, Department of Immunology, Institute of Child Health, 30 Guilford Street, London WC1N 1EH. 